\title{
Front Matter: Volume 9165
}

, "Front Matter: Volume 9165," Proc. SPIE 9165, Physical Chemistry of Interfaces and Nanomaterials XIII, 916501 (16 September 2014); doi: $10.1117 / 12.2081199$

SPIE Event: SPIE NanoScience + Engineering, 2014, San Diego, California, United SPIE. States 


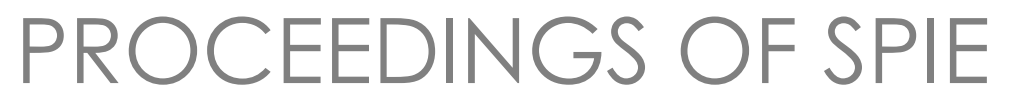

\section{Physical Chemistry of Interfaces and Nanomaterials XIII}

Natalie Banerji

Sophia C. Hayes

Carlos Silva

Editors

\section{7-20 August 2014}

San Diego, California, United States

Sponsored and Published by

SPIE 
The papers included in this volume were part of the technical conference cited on the cover and title page. Papers were selected and subject to review by the editors and conference program committee. Some conference presentations may not be available for publication. The papers published in these proceedings reflect the work and thoughts of the authors and are published herein as submitted. The publisher is not responsible for the validity of the information or for any outcomes resulting from reliance thereon.

Please use the following format to cite material from this book:

Author(s), "Title of Paper," in Physical Chemistry of Interfaces and Nanomaterials XIII, edited by Natalie Banerji, Sophia C. Hayes, Carlos Silva, Proceedings of SPIE Vol. 9165 (SPIE, Bellingham, WA, 2014) Article CID Number.

ISSN: 0277-786X

ISBN: 9781628411928

Published by

SPIE

P.O. Box 10, Bellingham, Washington 98227-0010 USA

Telephone +1 3606763290 (Pacific Time) · Fax +1 3606471445

SPIE.org

Copyright (@ 2014, Society of Photo-Optical Instrumentation Engineers.

Copying of material in this book for internal or personal use, or for the internal or personal use of specific clients, beyond the fair use provisions granted by the U.S. Copyright Law is authorized by SPIE subject to payment of copying fees. The Transactional Reporting Service base fee for this volume is $\$ 18.00$ per article (or portion thereof), which should be paid directly to the Copyright Clearance Center (CCC), 222 Rosewood Drive, Danvers, MA 01923. Payment may also be made electronically through CCC Online at copyright.com. Other copying for republication, resale, advertising or promotion, or any form of systematic or multiple reproduction of any material in this book is prohibited except with permission in writing from the publisher. The CCC fee code is 0277-786X/14/\$18.00.

Printed in the United States of America.

Publication of record for individual papers is online in the SPIE Digital Library.

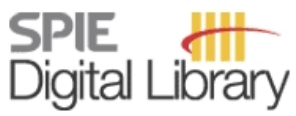

SPIEDigitalLibrary.org

Paper Numbering: Proceedings of SPIE follow an e-First publication model, with papers published first online and then in print and on CD-ROM. Papers are published as they are submitted and meet publication criteria. A unique, consistent, permanent citation identifier (CID) number is assigned to each article at the time of the first publication. Utilization of CIDs allows articles to be fully citable as soon as they are published online, and connects the same identifier to all online, print, and electronic versions of the publication. SPIE uses a six-digit CID article numbering system in which:

- The first four digits correspond to the SPIE volume number.

- The last two digits indicate publication order within the volume using a Base 36 numbering

system employing both numerals and letters. These two-number sets start with 00, 01, 02, 03, 04, 05, 06, 07, 08, 09, 0A, 0B ... 0Z, followed by 10-1Z, 20-2Z, etc.

The CID Number appears on each page of the manuscript. The complete citation is used on the first page, and an abbreviated version on subsequent pages. Numbers in the index correspond to the last two digits of the six-digit CID Number. 


\title{
Contents
}

\author{
$\checkmark$ Authors \\ vii Conference Committee \\ ix Introduction
}

\section{CHARGE GENERATION AT ORGANIC INTERFACES I}

916508 Competing role of quantum localization and interfacial disorder in determining triplet exciton fission and recombination dynamics in polymer/fullerene photovoltaics (Invited Paper) [9165-7]

\section{CHARGE GENERATION AT ORGANIC INTERFACES II}

916509 Two-dimensional polaron coherence in Poly(3-hexylthiophene) (Invited Paper) [9165-8]

9165 OC X-ray photoemission spectroscopy study of vertical phase separation in F8BT:PDI/ITO films for photovoltaic applications [9165-11]

SPECTROSCOPIC TECHNIQUES TO PROBE KINETICS OF ENERGY AND CHARGE TRANSFER AT INTERFACES

9165 0J Exciton hopping in carbon nanotube solar cells studied with 2D white-light spectroscopy (Invited Paper) [9165-18]

9165 OK Direct measurement of energy transport in organic nanosystems (Invited Paper) [9165-19]

$9165 \mathrm{OL}$ Optical properties of conjugated materials and their aggregates: towards imaging of films and devices [9165-20]

\section{PHOTOPHYSICS AT HYBRID INTERFACES}

$91650 \mathrm{~N}$ Two-electron photo-oxidation of betanin on titanium dioxide and potential for improved dye-sensitized solar energy conversion (Invited Paper) [9165-22]

9165 OP Ultrafast electron transfer from low band gap conjugated polymer to quantum dots in hybrid photovoltaic materials (Invited Paper) [9165-24]

\section{HYBRID AND INORGANIC NANOMATERIALS I}

9165 OS Effect of atomic under-coordination on the properties of Ag and Cu nanoclusters [9165-27] 
9165 OT Spectroelectrochemical photoluminescence of titanium dioxide nanosheets and nanoparticles in aqueous and nonaqueous environments [9165-28]

9165 OU Ultrafast infrared spectroscopy reveals intragap states in methylammonium lead iodide perovskite materials (Invited Paper) [9165-29]

PROPERTIES AND APPLICATIONS OF NOVEL PEROVSKITE-BASED NANOMATERIALS I

9165 OY The photophysics of perovskite solar cells (Invited Paper) [9165-33]

CHARGE TRANSFER AT THE ORGANIC HETEROJUNCTION I: JOINT SESSION WITH CONFERENCES 9165 AND 9184

$91650 Z$ Optical properties of low bandgap copolymer PTB7 for organic photovoltaic applications (Invited Paper) [9165-34]

HYBRID AND INORGANIC NANOMATERIALS II

916516 Assessment of cytotoxicity and oxidative effect of Bismuth Ferrite (BFO) harmonic nanoparticles for localized DNA photo-interaction (Invited Paper) [9165-41]

916519 Quantum dots: using the known as well as exploring the unknown (Invited Paper) [9165-44]

PHYSICAL UNDERSTANDING OF BIOLOGICAL SYSTEMS

9165 1E Drug/protein interactions studied by time-resolved fluorescence spectroscopy (Invited Paper) [9165-49]

9165 IF PEGylated nanoparticles: protein corona and secondary structure (Invited Paper) [9165-50]

$9165 \mathrm{1H} \quad$ Role of ZnS shell on stability, cytotoxicity, and photocytotoxicity of water-soluble CdSe semiconductor quantum dots surface modified with glutathione [9165-71]

POSTER SESSION

$91651 \mathrm{~N}$ A striking mobility improvement of $\mathrm{C}_{60}$ OFET by inserting diindenoperylene layer between $\mathrm{C}_{60}$ and $\mathrm{SiO}_{2}$ gate insulator [9165-58]

916510 Preparation of flexible $\mathrm{TiO}_{2}$ photoelectrodes for dye-sensitized solar cells [9165-59] 


\section{Authors}

Numbers in the index correspond to the last two digits of the six-digit citation identifier (CID) article numbering system used in Proceedings of SPIE. The first four digits reflect the volume number. Base 36 numbering is employed for the last two digits and indicates the order of articles within the volume. Numbers start with 00, 01, 02, 03, 04, 05, 06, 07, 08, 09, OA, OB...0Z, followed by 10-1Z, 20-2Z, etc.

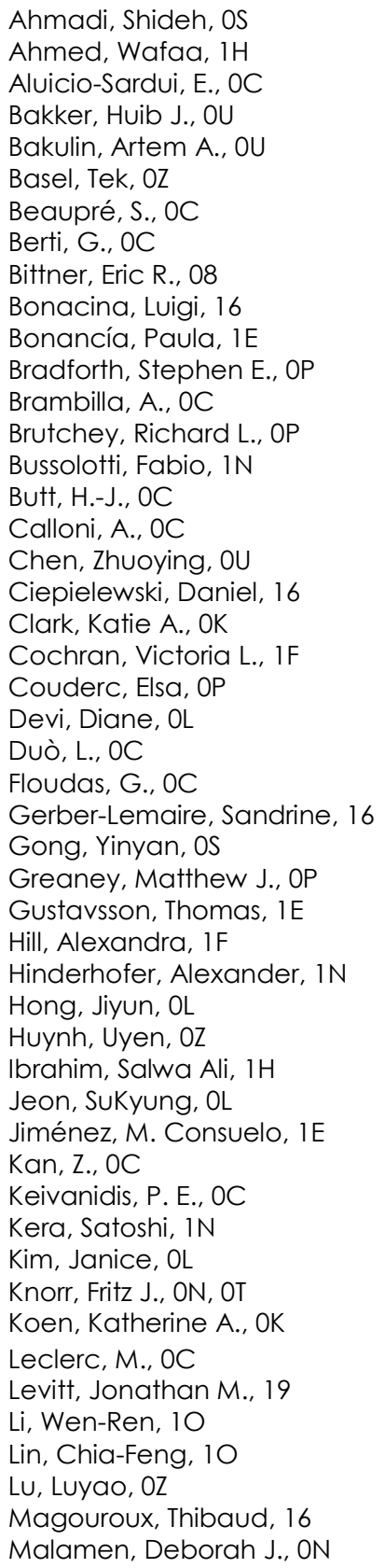

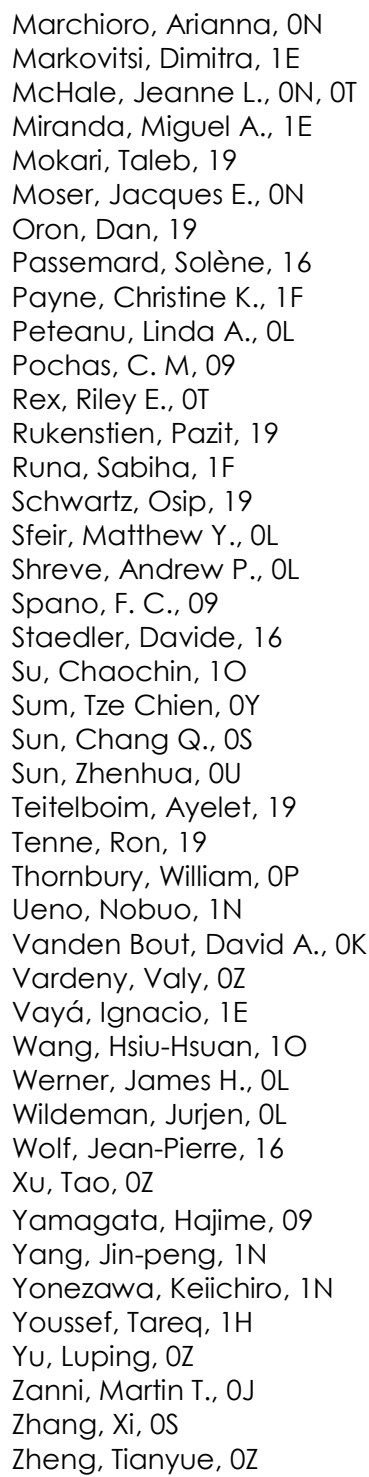


Proc. of SPIE Vol. $9165916501-6$

Downloaded From: https://www.spiedigitallibrary.org/conference-proceedings-of-spie on 26 Apr 2023 Terms of Use: https://www.spiedigitallibrary.org/terms-of-use 


\section{Conference Committee}

Symposium Chairs

Satoshi Kawata, Osaka University (Japan)

Manijeh Razeghi, Northwestern University (United States)

Symposium Co-chairs

David L. Andrews, University of East Anglia Norwich (United Kingdom)

James G. Grote, Air Force Research Laboratory (United States)

Conference Chairs

Natalie Banerji, Ecole Polytechnique Fédérale de Lausanne

(Switzerland)

Sophia C. Hayes, University of Cyprus (Cyprus)

Conference Co-chair

Carlos Silva, Université de Montréal (Canada)

Conference Program Committee

John B. Asbury, The Pennsylvania State University (United States)

Jenny Clark, University of Cambridge (United Kingdom)

Gitti Frey, Technion-Israel Institute of Technology (Israel)

Alexandre Fürstenberg, Université de Genève (Switzerland)

Oleg V. Prezhdo, University of Rochester (United States)

Sergei Tretiak, Los Alamos National Laboratory (United States)

Lauren Webb, The University of Texas at Austin (United States)

\section{Session Chairs}

1 Singlet Exciton Fission in Organic Semiconductors

Eric R. Bittner, University of Houston (United States)

2 Charge Generation at Organic Interfaces I

Natalie Banerji, Ecole Polyłechnique Fédérale de Lausanne

(Switzerland)

3 Charge Generation at Organic Interfaces II

David S. Ginger, University of Washington (United States) 
$4 \quad$ Charge Transfer Across Device Interfaces

Natalie Stingelin, Imperial College London (United Kingdom)

5 Spectroscopic Techniques to Probe Kinetics of Energy and Charge Transfer at Interfaces

Jeanne L. McHale, Washington State University (United States)

6 Photophysics at Hybrid Interfaces

David A. Vanden Bout, The University of Texas at Austin (United States)

$7 \quad$ Hybrid and Inorganic Nanomaterials I

Charles Schmuttenmaer, Yale University (United States)

8 Properties and Applications of Novel Perovskite-based

Nanomaterials I

Nripan Mathews, Nanyang Technological University (Singapore)

9 Charge Transfer at the Organic Heterojunction I: Joint Session with Conferences 9165 and 9184

Barry P. Rand, Princeton University (United States)

10 Charge Transfer at the Organic Heterojunction II: Joint Session with Conferences 9165 and 9184

Z. Valy Vardeny, The University of Utah (United States)

11 Emerging Experimental Tools for Biophysics

Luigi Bonacina, Université de Genève (Switzerland)

12 Hybrid and Inorganic Nanomaterials II

Artem A. Bakulin, FOM Institute for Atomic and Molecular Physics (Netherlands)

13 Properties and Applications of Novel Perovskite-based Nanomaterials II

Jacques E. Moser, Ecole Polytechnique Fédérale de Lausanne (Switzerland)

14 Physical Understanding of Biological Systems

Sophia C. Hayes, University of Cyprus (Cyprus) 


\section{Introduction}

Interfaces play a key role in the function of a plethora of chemical systems spanning the range from biological membranes, solid state materials, catalysts, all the way to organic bulk heterojunction materials for photovoltaics. The "Physical Chemistry of Interfaces and Nanomaterals" Conference provides a venue for the intermixing of physical chemists, physicists, biophysicists, and chemical engineers that can foster new ideas that can advance each other's field.

This year's thirteenth edition of the conference moved along the spirit of previous years including sessions on charge generation at organic interfaces, charge transfer across device interfaces, photophysics of hybrid photovoltaic systems, hybrid and inorganic nanomaterials, and physical understanding of biological systems. Two sessions were dedicated to properties and applications of novel perovskite-based nanomaterials, given the heightened recent interest of the optoelectronics community in these materials, and one session to singlet exciton fission in organic semiconductors. A new feature this year was also the inclusion of sessions dedicated to experimental methods for probing kinetics of energy and charge transfer at interfaces as well as emerging experimental tools for biophysics.

The common interest in organic photovoltaics spurred two joint sessions this year with the "Organic Photovoltaics XV" conference on charge transfer at the organic heterojunction. A real melting pot of experimentalists striving for uncovering the fundamental mechanisms behind device efficiencies, others discovering novel spectroscopic methods to study those interfaces and theoreticians modelling charge generation processes.

Overall, this was an exciting conference with lively discussions and fruitful exchanges of ideas.

We are grateful to SPIE, the Organizing Committee and most of all to the speakers that contributed to the success of this meeting.

Natalie Banerji Sophia C. Hayes Carlos Silva 
Proc. of SPIE Vol. $9165916501-10$

Downloaded From: https://www.spiedigitallibrary.org/conference-proceedings-of-spie on 26 Apr 2023 Terms of Use: https://www.spiedigitallibrary.org/terms-of-use 